\title{
Topology, Distance, and Orbital Symmetry Effects on Electronic Spin-Spin Couplings in Rigid Molecular Systems: Implications for Long Distance Spin-Spin Interactions
}

Ruobing Wang, ${ }^{1}$ Chih-Hung Ko, ${ }^{1}$ Alexander M. Brugh, ${ }^{2}$ Yusong Bai, ${ }^{1}$ Malcolm D. E. Forbes, ${ }^{2}$ and Michael J. Therien*1

${ }^{1}$ Department of Chemistry, Duke University, Durham, North Carolina 27708

${ }^{2}$ Center for Pure \& Applied Photosciences and Department of Chemistry, Bowling Green State University, Bowling Green, Ohio 43403

\section{Corresponding Authors}

*E-mail: forbesm@bgsu.edu

*E-mail: michael.therien@duke.edu

\section{Contents}

$\begin{array}{ll}\text { (1) Experimental Methods } & \text { S2 }\end{array}$

(2) Synthetic Procedures $\quad$ S3

(3) Electronic Absorption Spectroscopy $\quad$ S9

$\begin{array}{lr}\text { (4) Additional EPR Data } & \text { S10 }\end{array}$

$\begin{array}{ll}\text { (5) References } & \text { S13 }\end{array}$ 


\section{Experimental Methods}

Synthesis. The general synthetic routes to the $\beta \beta-\mathrm{PCu}_{2}$ and $m m-\mathrm{PCu}_{2}$ structures examined in this study are provided in Synthetic Procedures.

Steady-State EPR Spectroscopy. All EPR spectra were acquired on either a JEOL JES FA-100 or JEOL JES X310 spectrometer operating at X-band $(9.5 \mathrm{GHz})$ using a TE011 cylindrical microwave resonator with $100 \mathrm{kHz}$ field modulation. Samples were rigorously degassed with three consecutive freeze-pump-thaw cycles on a vacuum line. Experimental conditions: scan time $=8$ min, output time constant $=0.3 \mathrm{~s}$, sweep width $=2000$ Gauss (centered at $3140 \mathrm{Gauss}$ ); $100 \mathrm{kHz}$ field modulation amplitudes were typically 8 Gauss. For variable temperature studies (258-363 K) the microwave resonator was equipped with a quartz Dewar with flowing nitrogen gas for low temperatures and warm compressed air for high temperatures. All temperature readings are $\pm 1 \mathrm{~K}$.

Spectra simulation. Our simulation routine for bis[(porphinato)copper(II)] complex EPR spectra has been reported previously. ${ }^{1-2}$

Absorption Spectroscopy. Spectra were recorded on a SHIMADZU UV-1700 UV-Visible spectrophotometer. 


\section{Synthetic Procedures}

The syntheses of several $m m-\mathrm{PCu}_{2}$ complexes were reported previously. ${ }^{3-5} \mathrm{~A}$ graphical summary of the synthetic procedures to $\beta \beta-\mathrm{PCu}_{2}$ complexes, and new $m m-\mathrm{PCu}_{2}$ structures are given in Figures S1-2.

The syntheses of bis[2,2'-5,10,15,20-tetraphenyl(porphinato)zinc(II)]ethyne $(\mathbf{P Z n}(\boldsymbol{\beta})$-E- $(\boldsymbol{\beta}) \mathbf{P Z n})$, bis[2,2'-5, 10,15,20-tetraphenyl(porphinato)zinc(II)]butadiyne (PZn( $\left.\boldsymbol{\beta})-\mathbf{E}_{2}-(\boldsymbol{\beta}) \mathbf{P Z n}\right)$, (2-bromo5,10,15,20-tetraphenyporphinato)copper(II)

$(\mathbf{P C u}(\boldsymbol{\beta})-\mathrm{Br})$,

(2-ethynyl-5, 10,15,20tetraphenylporphinato)zinc(II) $(\mathbf{P Z n}(\boldsymbol{\beta})$-E-H), [5, 15-bis-ethynyl-10,20-di(2',6',-bis(33-dimethyl1-butyloxy)phenyl)porphinato]zinc(II) $(\mathbf{H}-\mathbf{E}-(m) \mathbf{P Z n}(m)-\mathbf{E}-\mathbf{H}), \operatorname{PZn}(m) \mathbf{E}_{3}(m) \mathbf{P Z n}$, and H-E$(m) \mathbf{P Z n}_{2}(\boldsymbol{m})$-E-H have been reported previously. ${ }^{5-6}$

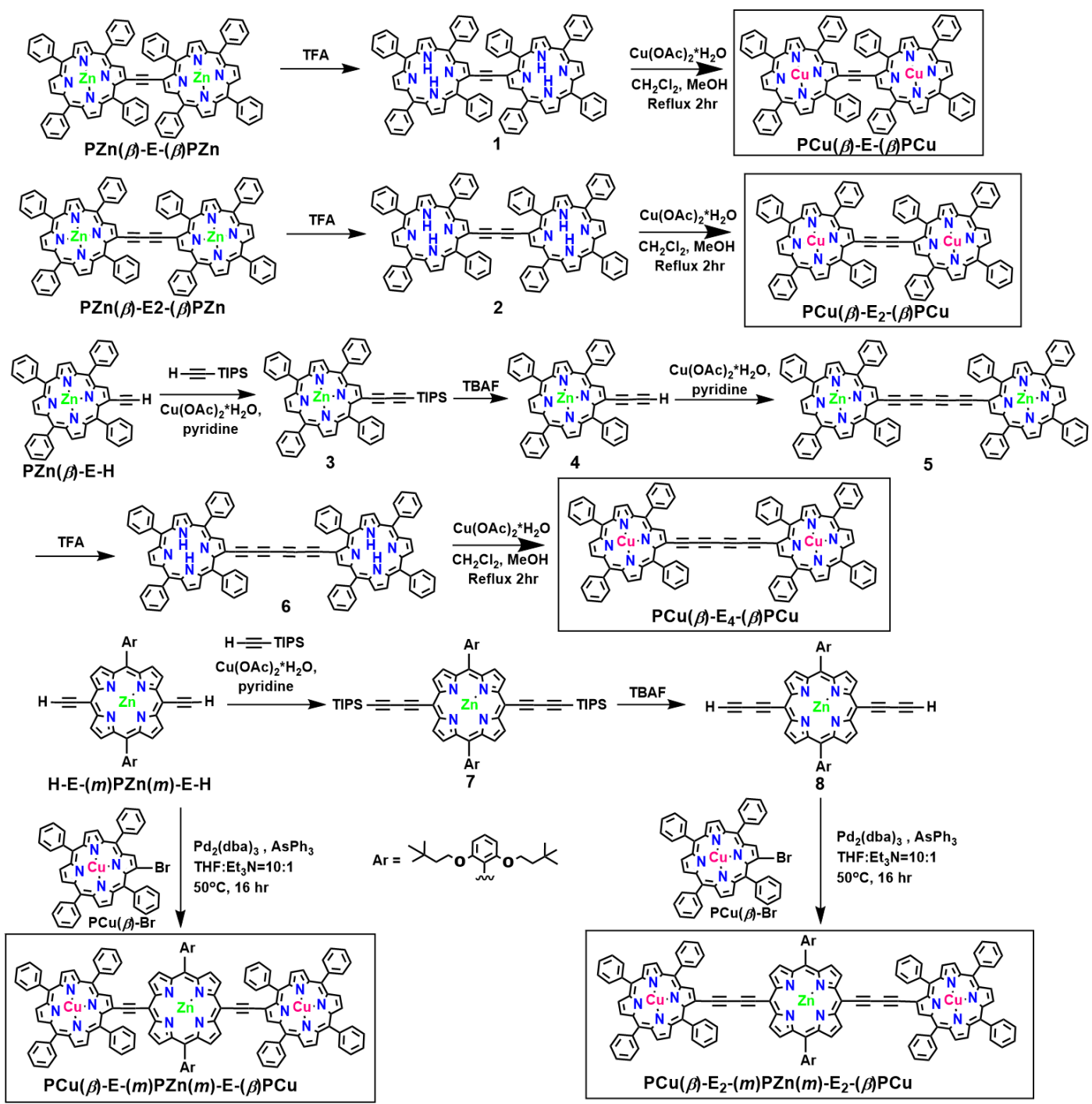

Figure S1. Overview of synthetic routes to the $\beta \beta-\mathrm{PCu}_{2}$ complexes studied in this work. 


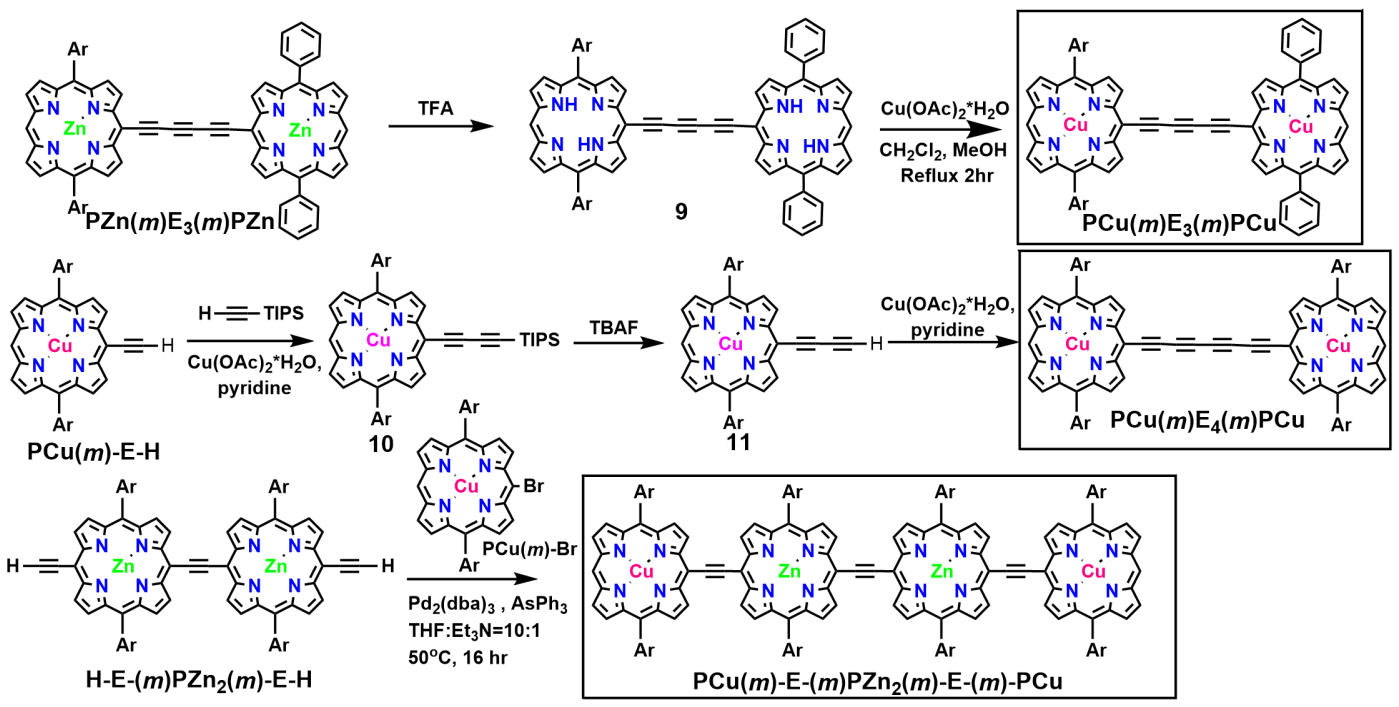

Figure S2. Overview of synthetic strategies employed to produce the $m m-\mathrm{PCu}_{2}$ complexes studied in this work.

Bis(2,2'-5,10,15,20-tetraphenylporphyrin)ethyne (compound 1). $1 \mathrm{~mL}$ of TFA was added to $\mathbf{P Z n}(\boldsymbol{\beta})-\mathbf{E}-(\boldsymbol{\beta}) \mathbf{P Z n}(37 \mathrm{mg}, 0.027 \mathrm{mmol})$ in $20 \mathrm{~mL}$ of $\mathrm{CH}_{2} \mathrm{Cl}_{2}$. The reaction was stirred for $30 \mathrm{~min}$. The mixture was poured into water $(10 \mathrm{~mL})$. After adding $\mathrm{CHCl}_{3}(10 \mathrm{~mL})$, the organic layer was washed with water (x2), sat. $\mathrm{NaHCO}_{3}$ (aq.):water (v/v 50\%/50\%), and water, and then dried over $\mathrm{MgSO}_{4}$. The crude product was chromatographed on silica gel using 1:1 hexanes: $\mathrm{CH}_{2} \mathrm{Cl}_{2}$ as eluent, then recrystallized in $\mathrm{CH}_{2} \mathrm{Cl}_{2} / \mathrm{MeOH}$ to afford compound 1 (29 $\mathrm{mg}, 85 \%$ yield based on $37 \mathrm{mg}$ of

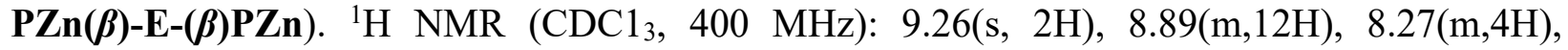
8.20(m,12H), $7.97(\mathrm{~m}, 4 \mathrm{H}), 7.83(\mathrm{~m}, 2 \mathrm{H}), 7.75(\mathrm{~m}, 18 \mathrm{H}),-2.16(\mathrm{~s}, 4 \mathrm{H})$. Vis (THF): 423, 522, 577, $603,658 \mathrm{~nm}$. MALDI-TOF MS $\left(\mathrm{M}^{+}\right)=1250.8($ calcd 1251.48).

Bis $\left[\left(2,2^{\prime}-5,10,15,20\right.\right.$-tetraphenylporphinato)copper(II)]ethyne (PCu( $\left.\boldsymbol{\beta}\right)$-E-( $\left.\left.\boldsymbol{\beta}\right) \mathbf{P C u}\right)$. A $100 \mathrm{~mL}$ flask was charged with 1:1 $\mathrm{CH}_{2} \mathrm{Cl}_{2}$ :methanol (40 mL), compound 1 (25 mg, $\left.0.02 \mathrm{mmol}\right)$, copper(II) acetate hydrate ( $36 \mathrm{mg}, 10$ eq.) and refluxed for $3 \mathrm{~h}$. After cooling the mixture to room temperature, the solution was washed with water, separated and evaporated. The red residue was redissolved in a minimal amount of $1: 1$ hexanes: $\mathrm{CH}_{2} \mathrm{Cl}_{2}$, and purified by column chromatography using the same eluent, giving $26 \mathrm{mg}$ of product (95\% yield, based on $26 \mathrm{mg}$ of compound 1). Vis (THF): 421 , 552, $602 \mathrm{~nm}$. MALDI-TOF MS $\left(\mathrm{M}^{+}\right)=1374.6($ calcd 1374.54).

Bis(2,2'-5,10,15,20-tetraphenylporphyrin)butadiyne (compound 2$) .1 \mathrm{~mL}$ of TFA was added to $\mathbf{P Z n}(\boldsymbol{\beta})-\mathbf{E}_{2}-(\boldsymbol{\beta}) \mathbf{P Z n}(35 \mathrm{mg}, 0.025 \mathrm{mmol})$ in $20 \mathrm{~mL}$ of $\mathrm{CH}_{2} \mathrm{Cl}_{2}$. The reaction was stirred for 30 min. The mixture was poured into water $(10 \mathrm{~mL})$. After adding $\mathrm{CHC1}_{3}(10 \mathrm{~mL})$, the organic layer was washed with water (x2), sat. $\mathrm{NaHCO}_{3}$ (aq.): water (v/v 50\%/50\%), and water, and then dried over $\mathrm{MgSO}_{4}$. The crude product was chromatographed on silica gel using 1:1 hexanes: $\mathrm{CH}_{2} \mathrm{Cl}_{2}$ as eluent then recrystallized in $\mathrm{CH}_{2} \mathrm{Cl}_{2} / \mathrm{MeOH}$ to afford compound 2 (26 $\mathrm{mg}, 81 \%$ yield based on 35 mg of PZn( $\left.\boldsymbol{\beta})-\mathbf{E}_{2}-(\boldsymbol{\beta}) \mathbf{P Z n}\right) .{ }^{1} \mathrm{H}$ NMR $\left(\mathrm{CDC1}_{3}, 400 \mathrm{MHz}\right)$ : 9.15(s, 2H), 8.74(m,12H), 8.11(m,16H), $7.65(\mathrm{~m}, 24 \mathrm{H}),-2.16(\mathrm{~s}, 4 \mathrm{H})$.Vis (THF): 426, 524, 563, 603, $659 \mathrm{~nm}$. MALDI-TOF MS(M $\left.{ }^{+}\right)$ $=1275.8($ calcd 1275.5$)$. 
Bis[(2,2'-5,10,15,20-tetraphenylporphinato)copper(II)]butadiyne (PCu( $\left.\boldsymbol{\beta})-\mathrm{E}_{2}-(\boldsymbol{\beta}) \mathbf{P C u}\right)$. A 100 $\mathrm{mL}$ flask was charged with 1:1 $\mathrm{CH}_{2} \mathrm{Cl}_{2}$ :methanol $(40 \mathrm{~mL})$, compound $2(25 \mathrm{mg}, 0.02 \mathrm{mmol})$, copper(II) acetate hydrate ( $36 \mathrm{mg}, 10 \mathrm{eq}$.) and refluxed for $3 \mathrm{~h}$. After cooling the mixture to room temperature, the solution was washed with water, separated and evaporated. The red residue was redissolved in a minimal amount of $1: 1$ hexanes: $\mathrm{CH}_{2} \mathrm{Cl}_{2}$, and purified by column chromatography using the same eluent, giving $26 \mathrm{mg}$ of product (95\% yield, based on $25 \mathrm{mg}$ of compound 2 . Vis (THF): 426, 552, $599 \mathrm{~nm}$. MALDI-TOF MS(M $\left.{ }^{+}\right)=1374.6$ (calcd 1374.54).

(2-Triisopropylsilylbutadiynyl-5,10,15,20-tetraphenylporphinato)zinc(II) (compound 3). A $25-\mathrm{ml}$ round bottom bottle equipped with a magnetic stirring bar was charged with $\mathbf{P Z n}(\boldsymbol{\beta})$-E-H (50 mg, $0.07 \mathrm{mmol})$, (triisopropylsilyl)acetylene (63.8 mg, 5 eq.), $\mathrm{Cu}(\mathrm{OAc})_{2}(40 \mathrm{mg}, 0.2 \mathrm{mmol})$, and $5 \mathrm{ml}$ of pyridine. The mixture was then warmed and stirred at $90{ }^{\circ} \mathrm{C}$ for $1 \mathrm{~h}$. The solution was quenched with $\mathrm{H}_{2} \mathrm{O}$. A crude dark-green precipitate was collected, re-dissolved in $\mathrm{CH}_{2} \mathrm{Cl}_{2}$, dried over $\mathrm{NaSO}_{4}$, and purified by column chromatography on silica with 7:3 hexanes:THF as eluent. A dark-green band was collected and evaporated to yield $48 \mathrm{mg}$ of compound 3 ( $78 \%$ yield, based on $50 \mathrm{mg}$ of PZn( $\boldsymbol{\beta})$-E-H). ${ }^{1} \mathrm{H}$ NMR $\left(\mathrm{CDCl}_{3}, 400 \mathrm{MHz}\right): 9.27(\mathrm{~s}, 1 \mathrm{H}), 8.92(\mathrm{~m}, 6 \mathrm{H}), 8.19(\mathrm{~m}, 8$ $\mathrm{H}), 7.75(\mathrm{~m}, 12 \mathrm{H})$, and $1.29(\mathrm{~s}, 21 \mathrm{H})$. Vis (THF): 436, 567, $603 \mathrm{~nm}$. MALDI-TOF MS(M $\mathrm{M}^{+}=882.6$ (calcd 882.48).

(2-Butadiynyl-5,10,15,20-tetraphenylporphinato)zinc(II) (compound 4). TBAF ( $0.1 \mathrm{M}$ in THF, $0.92 \mathrm{ml}, 0.092 \mathrm{mmol}$ ) was added to compound $3(30 \mathrm{mg}, 0.034 \mathrm{mmol})$ in $10 \mathrm{ml}$ of THF at $0{ }^{\circ} \mathrm{C}$. After $10 \mathrm{~min}$, the solution was poured onto a plug of silica gel then eluted with $\mathrm{CH}_{2} \mathrm{Cl}_{2}$. After the solvent was evaporated, the residue was chromatographed over silica gel using 1:5 THF:hexanes as eluent to afford $22 \mathrm{mg}$ of compound 4 ( $90 \%$ yield, based on $30 \mathrm{mg}$ of compound 3 ). ${ }^{1} \mathrm{H}$ NMR $\left(\mathrm{CDCl}_{3}, 400 \mathrm{MHz}\right)$ : $9.27(\mathrm{~s}, 1 \mathrm{H}), 8.92(\mathrm{~m}, 6 \mathrm{H}), 8.19(\mathrm{~m}, 8 \mathrm{H}), 7.75(\mathrm{~m}, 12 \mathrm{H})$, and $4.03(\mathrm{~s}, 1 \mathrm{H})$. Vis (THF): 435, 566, $604 \mathrm{~nm}$. MALDI-TOF MS(M $\left.{ }^{+}\right)=726.3$ (calcd 726.14).

Bis[(2,2'-5,10,15,20-tetraphenylporphinato)zinc(II)]octatetrayne (compound 5). A 25-ml round bottom bottle equipped with a magnetic stirring bar was charged with compound $4(15 \mathrm{mg}$, $0.02 \mathrm{mmol}), \mathrm{Cu}(\mathrm{OAc})_{2}(10 \mathrm{mg}, 0.05 \mathrm{mmol})$, and $3 \mathrm{ml}$ of pyridine. The mixture was then warmed and stirred at $90{ }^{\circ} \mathrm{C}$ for $1 \mathrm{~h}$. The solution was quenched with $\mathrm{H}_{2} \mathrm{O}$. A crude dark-green precipitate was collected, re-dissolved in $\mathrm{CH}_{2} \mathrm{Cl}_{2}$, dried over $\mathrm{NaSO}_{4}$, and purified by column chromatography on silica with 7:3 hexanes:THF as eluent. A dark-green band was collected and evaporated to yield $12 \mathrm{mg}$ of compound 5 (83\% yield, based on $15 \mathrm{mg}$ of compound 4). ${ }^{1} \mathrm{H} \mathrm{NMR} \mathrm{(CDC1}{ }_{3}, 400 \mathrm{MHz}$ ): $9.27(\mathrm{~s}, 2 \mathrm{H}), 8.92(\mathrm{~m}, 12 \mathrm{H}), 8.19(\mathrm{~m}, 16 \mathrm{H})$, and $7.75(\mathrm{~m}, 24 \mathrm{H})$. Vis (10:1 $\mathrm{CHCl}_{3}$ :pyridine): 452, $479,583,620 \mathrm{~nm}$. MALDI-TOF MS(M $\left.{ }^{+}\right)=1450.4($ calcd 1450.27).

Bis(2,2'-5,10,15,20-tetraphenylporphyrin)octatetrayne (compound 6). $1 \mathrm{~mL}$ of TFA was added to compound 5 (12 mg, $0.008 \mathrm{mmol})$ in $20 \mathrm{~mL}$ of $\mathrm{CH}_{2} \mathrm{Cl}_{2}$. The reaction was stirred for $30 \mathrm{~min}$. The mixture was poured into water $(10 \mathrm{~mL})$. After adding $\mathrm{CHCl}_{3}(10 \mathrm{~mL})$, the organic layer was washed with water (x2), sat. $\mathrm{NaHCO}_{3}$ (aq.): water (v/v 50\%/50\%), and water, and then dried over $\mathrm{MgSO}_{4}$. The crude product was chromatographed on silica gel using 1:1 hexanes: $\mathrm{CH}_{2} \mathrm{Cl}_{2}$ as eluent then recrystallized in $\mathrm{CH}_{2} \mathrm{Cl}_{2} / \mathrm{MeOH}$ to afford compound 6 (11 mg, 96\% yield based on $12 \mathrm{mg}$ of compound 5). ${ }^{1} \mathrm{H}$ NMR $\left(\mathrm{CDCl}_{3}, 400 \mathrm{MHz}\right): 9.27$ (s, $\left.2 \mathrm{H}\right), 8.92$ (m, $\left.12 \mathrm{H}\right), 8.19$ (m, $\left.16 \mathrm{H}\right), 7.75$ $(\mathrm{m}, 24 \mathrm{H})$, and $-2.16(\mathrm{~s}, 4 \mathrm{H})$. Vis (THF): 432, 525, 573, 608, $663 \mathrm{~nm}$. MALDI-TOF MS(M $\left.\mathrm{M}^{+}\right)$ 
$=1323.5($ calcd 1323.54$)$.

$\operatorname{Bis}\left[\left(2,2^{\prime}-5,10,15,20-t e t r a p h e n y l p o r p h i n a t o\right) \operatorname{copper}(\mathrm{II})\right]$ octatetrayne $\left(\mathrm{PCu}(\boldsymbol{\beta})-\mathrm{E}_{4}-(\boldsymbol{\beta}) \mathbf{P C u}\right)$. A $50 \mathrm{~mL}$ flask was charged with $1: 1 \mathrm{CH}_{2} \mathrm{Cl}_{2}$ :methanol $(20 \mathrm{~mL}$ ), compound 6 (11 mg, $0.008 \mathrm{mmol})$, copper(II) acetate $(15 \mathrm{mg}, 10$ eq.) and refluxed for $3 \mathrm{~h}$. After cooling the mixture to room temperature, the solution was washed with water, separated and evaporated. The red residue was redissolved in a minimal amount of 1:1 hexane: $\mathrm{CH}_{2} \mathrm{Cl}_{2}$, and purified by column chromatography using the same eluent, giving $11 \mathrm{mg}$ of product (94\% yield, based on $11 \mathrm{mg}$ of compound 6). Vis (THF): 439, 557, $601 \mathrm{~nm}$. MALDI-TOF MS(M $\left.\mathrm{M}^{+}\right)=1446.60$ (calcd 1446.60).

5,15-Bis $\left\{\left[2^{\prime}-5 ', 10 ', 15 ', 20\right.\right.$ '-tetraphenylporphinato)copper(II)] ethynyl\}-10,20-bis[2,6-di(3,3dimethyl-1-butyloxy)phenyl]porphinato)zinc(II) $(\mathrm{PCu}(\beta)-\mathrm{E}-(m) \mathrm{PZn}(m)-\mathrm{E}-(\boldsymbol{\beta}) \mathrm{PCu}) . \mathrm{PCu}(\boldsymbol{\beta})$ $\mathbf{B r}(22 \mathrm{mg}, 0.029 \mathrm{~mol})$ and H-E-(m)PZn(m)-E-H (14 mg, $0.014 \mathrm{~mol}), 20 \mathrm{ml}$ of dry THF, and 2.0 $\mathrm{ml}$ of trimethylamine were added to a $50 \mathrm{~mL}$ Schlenk tube. $\mathrm{Pd}_{2}(\mathrm{dba})_{3}\left(0.019 \mathrm{~g}, 2.07 \times 10^{-5} \mathrm{~mol}\right)$ and $\mathrm{AsPh}_{3}(51 \mathrm{mg}, 0.017 \mathrm{mmol})$ were transferred to the Schlenk tube in a dry box, following which the solution was degassed by three successive freeze-pump-thaw cycles. The reaction mixture was stirred at $45{ }^{\circ} \mathrm{C}$ for $10.5 \mathrm{~h}$, after which time the solvent was evaporated, and the residue chromatographed on silica gel using 10:1 hexanes:THF as the eluent, giving $22 \mathrm{mg}$ of product (68\%, based on $14 \mathrm{mg}$ of H-E-(m)PZn(m)-E-H). Vis (THF): 421, 456, 547, 582, $648 \mathrm{~nm}$. MALDITOF $\operatorname{MS}\left(\mathrm{M}^{+}\right)=2323.1($ calcd 2323.09).

\section{[5,15-Bis-triisopropylsiIylbutadiynyl-10,20-di(2',6'-bis(3,3-dimethyl-l-butyloxy)-}

phenyl)porphinatolzinc(II) (compound 7). A $25-\mathrm{ml}$ round bottom bottle equipped with a magnetic stirring bar was charged with H-E- $(\boldsymbol{m}) \mathbf{P Z n}(\boldsymbol{m})-\mathbf{E}-\mathbf{H}(68 \mathrm{mg}, 0.07 \mathrm{mmol})$, (triisopropylsilyl)acetylene (128 mg, 10 eq.), $\mathrm{Cu}(\mathrm{OAc})_{2}(80 \mathrm{mg}, 0.4 \mathrm{mmol})$, and $5 \mathrm{ml}$ of pyridine. The mixture was then warmed and stirred at $90{ }^{\circ} \mathrm{C}$ for $1 \mathrm{~h}$. The solution was quenched with $\mathrm{H}_{2} \mathrm{O}$. A crude dark-green precipitate was collected, re-dissolved in $\mathrm{CH}_{2} \mathrm{Cl}_{2}$, dried over $\mathrm{NaSO}_{4}$, and purified by column chromatography on silica with 7:3 hexanes:THF as eluent. A dark-green band was collected and evaporated to yield $48 \mathrm{mg}$ of product (78\% yield, based on $68 \mathrm{mg}$ of H-E(m)PZn(m)-E-H). ${ }^{1} \mathrm{H}$ NMR (CDC1 3 , $\left.400 \mathrm{MHz}\right): 9.45$ (d, 4H), 8.68 (d, 4H), 7.62(t, 2H), 6.91 (d, 4H), $3.88(\mathrm{t}, 8 \mathrm{H}), 0.95(\mathrm{t}, 8 \mathrm{H}), 0.32$ (s, 36H). Vis (THF): 449, 630, $655 \mathrm{~nm}$. MALDI-TOF MS(M $\left.{ }^{+}\right)$ $=1335.6($ calcd 1335.31$)$.

[5,15-Bis-butadiynyl-10,20-di(2',6'-bis(3,3-dimethyl-l-butyloxy)phenyl)porphin-ato]zinc(II) (compound 8). TBAF (0.1 M in THF, $0.92 \mathrm{ml}, 0.092 \mathrm{mmol}$ ) was added to compound 7 ( $45 \mathrm{mg}$, $0.034 \mathrm{mmol}$ ) in $10 \mathrm{ml}$ of THF at $0{ }^{\circ} \mathrm{C}$. After $10 \mathrm{~min}$, the solution was poured onto a plug of silica gel then eluted with $\mathrm{CH}_{2} \mathrm{Cl}_{2}$. After the solvent was evaporated, the residue was chromatographed over silica gel using 1:5 THF:hexanes as eluent to afford $32 \mathrm{mg}$ of compound 8 ( $90 \%$ yield based on $45 \mathrm{mg}$ of compound 7). ${ }^{1} \mathrm{H} \mathrm{NMR}\left(\mathrm{CDCl}_{3}, 400 \mathrm{MHz}\right)$ : $9.45(\mathrm{~d}, 4 \mathrm{H}), 8.68(\mathrm{~d}, 4 \mathrm{H}), 7.62(\mathrm{t}, 2 \mathrm{H})$, $6.91(\mathrm{~d}, 4 \mathrm{H}), 4.04(\mathrm{~s}, 2 \mathrm{H}), 3.88(\mathrm{t}, 8 \mathrm{H}), 0.95(\mathrm{t}, 8 \mathrm{H})$. Vis (THF): 435, 566, $604 \mathrm{~nm}$. MALDI-TOF $\operatorname{MS}\left(\mathrm{M}^{+}\right)=1022.3($ calcd 1022.63$)$

5,15-Bis $\left\{\left[2^{\prime}-5^{\prime}, 10^{\prime}, 15,20\right.\right.$ '-tetraphenylporphinato)copper(II)]butadiynyl $\}-10,20-b i s[2,6-$ di(3,3-dimethyl-1-butyloxy)phenyl]porphinato)zinc(II) $\quad\left(\mathrm{PCu}(\beta)-\mathrm{E}_{2}-(m) \mathrm{PZn}(m)-\mathrm{E}_{2}-(\beta) \mathrm{PCu}\right)$. $\mathbf{P C u}(\boldsymbol{\beta})-\mathrm{Br}(22 \mathrm{mg}, 0.029 \mathrm{~mol})$ and compound $8(14 \mathrm{mg}, 0.014 \mathrm{~mol}), 20 \mathrm{ml}$ of dry THF, and 2.0 $\mathrm{ml}$ of trimethylamine were added to a $50 \mathrm{~mL}$ Schlenk tube. $\operatorname{Pd}_{2}(\mathrm{dba})_{3}(0.019 \mathrm{~g}, 0.021 \mathrm{mmol})$ and 
$\mathrm{AsPh}_{3}(51 \mathrm{mg}, 0.017 \mathrm{mmol})$ were transferred to the Schlenk tube in a dry box, following which the solution was degassed by three successive freeze-pump-thaw cycles. The reaction mixture was stirred at $45{ }^{\circ} \mathrm{C}$ for $10.5 \mathrm{~h}$, after which time the solvent was evaporated, and the residue chromatographed on silica gel using 10:1 hexanes:THF as the eluent, to give $22 \mathrm{mg}$ of product (68\%, based on $14 \mathrm{mg}$ of compound 8). Vis-NIR (THF): 421, 472, 552, 586, $702 \mathrm{~nm}$. MALDITOF MS $\left(\mathrm{M}^{+}\right)=2371.2($ calcd 2371.13$)$.

Compound 9. $1 \mathrm{~mL}$ of TFA was added to $\mathbf{P Z n}(\boldsymbol{m}) \mathbf{E}_{\mathbf{3}}(\boldsymbol{m}) \mathbf{P Z n}(20 \mathrm{mg}, 0.013 \mathrm{mmol})$ in $20 \mathrm{~mL}$ of $\mathrm{CH}_{2} \mathrm{Cl}_{2}$. The reaction was stirred for $30 \mathrm{~min}$. The mixture was poured into water $(10 \mathrm{~mL})$. After adding $\mathrm{CHCl}_{3}(10 \mathrm{~mL})$, the organic layer was washed with water (x2), sat. $\mathrm{NaHCO}_{3}$ (aq.): water (v/v 50\%/50\%), and water, and then dried over $\mathrm{MgSO}_{4}$. The crude product was chromatographed on silica gel using 1:1 hexanes: $\mathrm{CH}_{2} \mathrm{Cl}_{2}$ as eluent then recrystallized in $\mathrm{CH}_{2} \mathrm{Cl}_{2} / \mathrm{MeOH}$ to afford compound 9 (17 mg, 94\% yield based on $12 \mathrm{mg}$ of $\left.\mathbf{P Z n}(\boldsymbol{m}) \mathbf{E}_{\mathbf{3}}(\boldsymbol{m}) \mathbf{P Z n}\right),{ }^{1} \mathrm{H} \mathrm{NMR}\left(\mathrm{CDC1}_{3}, 400\right.$ MHz): $10.02(\mathrm{~s}, 1 \mathrm{H}), 10.01(\mathrm{~s}, 1 \mathrm{H}) 9.81(\mathrm{~d}, 2 \mathrm{H}), 9.71(\mathrm{~d}, 2 \mathrm{H}), 9.37$ (d, 2H), $9.14(\mathrm{~d}, 2 \mathrm{H}), 9.05$ (d, 2H), $8.88(\mathrm{~m}, 4 \mathrm{H}), 8.80(\mathrm{~d}, 2 \mathrm{H}), 8.21(\mathrm{~m}, 4 \mathrm{H}), 7.82(\mathrm{~m}, 6 \mathrm{H}), 7.76(\mathrm{t}, 2 \mathrm{H}), 7.04(\mathrm{~d}, 4 \mathrm{H}), 3.95(\mathrm{t}$, $8 \mathrm{H}), 1.27(\mathrm{t}, 8 \mathrm{H}), 0.36(\mathrm{~s}, 48 \mathrm{H}),-2.30(\mathrm{~s}, 2 \mathrm{H})$ and $-2.40(\mathrm{~s}, 2 \mathrm{H})$. MALDI-TOF MS(M $\left.\mathrm{M}^{+}\right)=1394.5$ (calcd 1395.81).

$\mathbf{P C u}(\boldsymbol{m}) \mathbf{E}_{\mathbf{3}}(\boldsymbol{m}) \mathbf{P C u}$. A $100 \mathrm{ml}$ flask was charged with 1:1 $\mathrm{CH}_{2} \mathrm{Cl}_{2}$ :methanol (40 $\left.\mathrm{mL}\right)$, compound 9 (17 mg, $0.012 \mathrm{mmol}$ ), copper(II) acetate (54 mg, 10 eq.), and refluxed for $3 \mathrm{~h}$. After cooling the mixture to room temperature, the solution was washed with water, separated, and evaporated. The green residue was then dissolved in a minimal amount of 1:1 hexanes: $\mathrm{CH}_{2} \mathrm{Cl}_{2}$, and purified by column chromatography using the same eluent, giving $18 \mathrm{mg}$ of product ( $94 \%$ yield, based on 17 mg of compound 9). Vis (THF): 445, 480, 560, $639 \mathrm{~nm}$. MALDI-TOF MS(M $\left.{ }^{+}\right)=1518.4$ (calcd 1518.87).

Compound 10. An oven-dried 50-ml Schlenk tube equipped with a magnetic stirring bar was charged with PCu(m)-E-H (70 mg, $0.084 \mathrm{mmol})$, (triisopropylsilyl)acetylene (154 mg, 10 eq.), and $4.2 \mathrm{ml}$ dry pyridine. The mixture was stirred under argon. $\mathrm{Cu}(\mathrm{OAc})_{2}(200 \mathrm{mg}, 1 \mathrm{mmol})$ was dissolved in $15 \mathrm{ml}$ of pyridine in a $25 \mathrm{ml}$-round bottom flask and heated to $60{ }^{\circ} \mathrm{C}$; this solution was then transferred to a Schlenk tube containing compound 8 by syringe. The solution was heated to $90{ }^{\circ} \mathrm{C}$ for $1 \mathrm{~h}$ and quenched by $\mathrm{H}_{2} \mathrm{O}$. The solvent was removed at reduced pressure and re-dissolved in $\mathrm{CH}_{2} \mathrm{Cl}_{2}$, dried over $\mathrm{Na}_{2} \mathrm{SO}_{4}$, and purified by column chromatography on silica with $7: 3$ hexanes:THF as eluent. The solution was evaporated to yield $67 \mathrm{mg}$ of compound 10 (71\% yield, based on $70 \mathrm{mg}$ of PCu(m)-E-H). Vis (toluene): 427, 540, $592 \mathrm{~nm}$. MALDI-TOF MS( $\left.\mathrm{M}^{+}\right)=1128.3$ (calcd 1129.12).

Compound 11. TBAF (0.1 M in THF, $2 \mathrm{ml}, 0.2 \mathrm{mmol})$ was added to compound 10 (60 $\mathrm{mg}, 0.053$ $\mathrm{mmol}$ ) in $30 \mathrm{ml}$ of $\mathrm{THF}$ at $0{ }^{\circ} \mathrm{C}$. After $20 \mathrm{~min}$, the solution was poured onto a plug of silica gel then eluted with $\mathrm{CH}_{2} \mathrm{Cl}_{2}$. After the solvent was evaporated under reduced pressure, the residue was chromatographed over silica gel using 1:1 $\mathrm{CH}_{2} \mathrm{Cl}_{2}$ :hexanes as eluent to afford $42 \mathrm{mg}$ of compound 11 (81\% yield, based on $60 \mathrm{mg}$ of compound 10), Vis (THF): 428, 550, 587, $630 \mathrm{~nm}$, MALDI-TOF MS(M+) $=971.7($ calcd 971.53).

$\mathbf{P C u}(m) \mathbf{E}_{4}(m) \mathbf{P C u}$. An oven-dried $50 \mathrm{ml}$ Schlenk tube equipped with a magnetic stirring bar was charged with compound $11(35 \mathrm{mg}, 0.036 \mathrm{mmol})$ and $2.1 \mathrm{ml}$ dry pyridine. The mixture was stirred 
under argon. $\mathrm{Cu}(\mathrm{OAc})_{2}(90 \mathrm{mg}, 0.45 \mathrm{mmol})$ and $10 \mathrm{ml}$ of pyridine in a $25 \mathrm{ml}$-round bottom flask was heated to $60^{\circ} \mathrm{C}$; this solution was then transferred to a Schlenk tube containing 10 by syringe. The solution was heated to $90{ }^{\circ} \mathrm{C}$ for $1 \mathrm{~h}$ and quenched by water. The solvent was removed at reduced pressure and re-dissolved in $\mathrm{CH}_{2} \mathrm{Cl}_{2}$, dried over $\mathrm{NaSO}_{4}$, and purified by column chromatography on silica with 7:3 hexanes:THF as eluent, followed by size exclusion chromatography using THF as eluent. After passing the material through a short silica plug using dichloromethane as eluent, $22 \mathrm{mg}$ of product was recovered after evaporation of solvent $(32 \%$ yield, based on $35 \mathrm{mg}$ of compound 11). Due to its solid-state instability, $\mathbf{P C u}(\boldsymbol{m}) \mathbf{E}_{\mathbf{4}}(\boldsymbol{m}) \mathbf{P C u}$ was stored at low temperature in dilute toluene solution. Vis (THF): 420, 455, 476, 554, 607, $632 \mathrm{~nm}$. MALDI-TOF MS $\left(\mathrm{M}^{+}\right)=1941.0($ calcd 1940.83).

$\mathbf{P C u}(\boldsymbol{m})$-E-( $\boldsymbol{m}) \mathbf{P Z n} \mathbf{n}_{2}(\boldsymbol{m})$-E-(m)-PCu. A $100 \mathrm{~mL}$ Schlenk tube was charged by H-E- $(\boldsymbol{m}) \mathbf{P Z n} \mathbf{n}_{2}(\boldsymbol{m})-$ E-H ( $80 \mathrm{mg}, 0.042 \mathrm{mmol})$ and $\mathbf{P C u}(\boldsymbol{m})-\mathbf{B r}(188 \mathrm{mg}, 0.187 \mathrm{mmol}) . \mathrm{Pd}_{2}(\mathrm{dba})_{3}(3.6 \mathrm{mg}, 0.004 \mathrm{mmol})$ and $\mathrm{AsPh}_{3}(1.5 \mathrm{mg}, 0.005 \mathrm{mmol})$ were transferred to the Schlenk tube in a glove box, following which the degassed solution mixed by $30 \mathrm{ml}$ of dry THF and $3.0 \mathrm{ml}$ of trimethylamine. The reaction mixture was stirred at $55^{\circ} \mathrm{C}$ overnight and monitored by TLC. The residue was chromatographed on size exclusion media and silica gel using 10:1 hexanes:THF as the eluent to afford $63 \mathrm{mg}$ of product (40\%, based on $80 \mathrm{mg}$ of H-E-( $\boldsymbol{m}) \mathbf{P Z n} \mathbf{n}_{\mathbf{2}}(\boldsymbol{m})$-E-H). Vis-NIR (THF): 408, 484, 509, $779 \mathrm{~nm}$. MALDI-TOF MS(M $\left.{ }^{+}\right)=3760.1($ calcd 3761.8). 


\section{Electronic Absorption Spectroscopy}

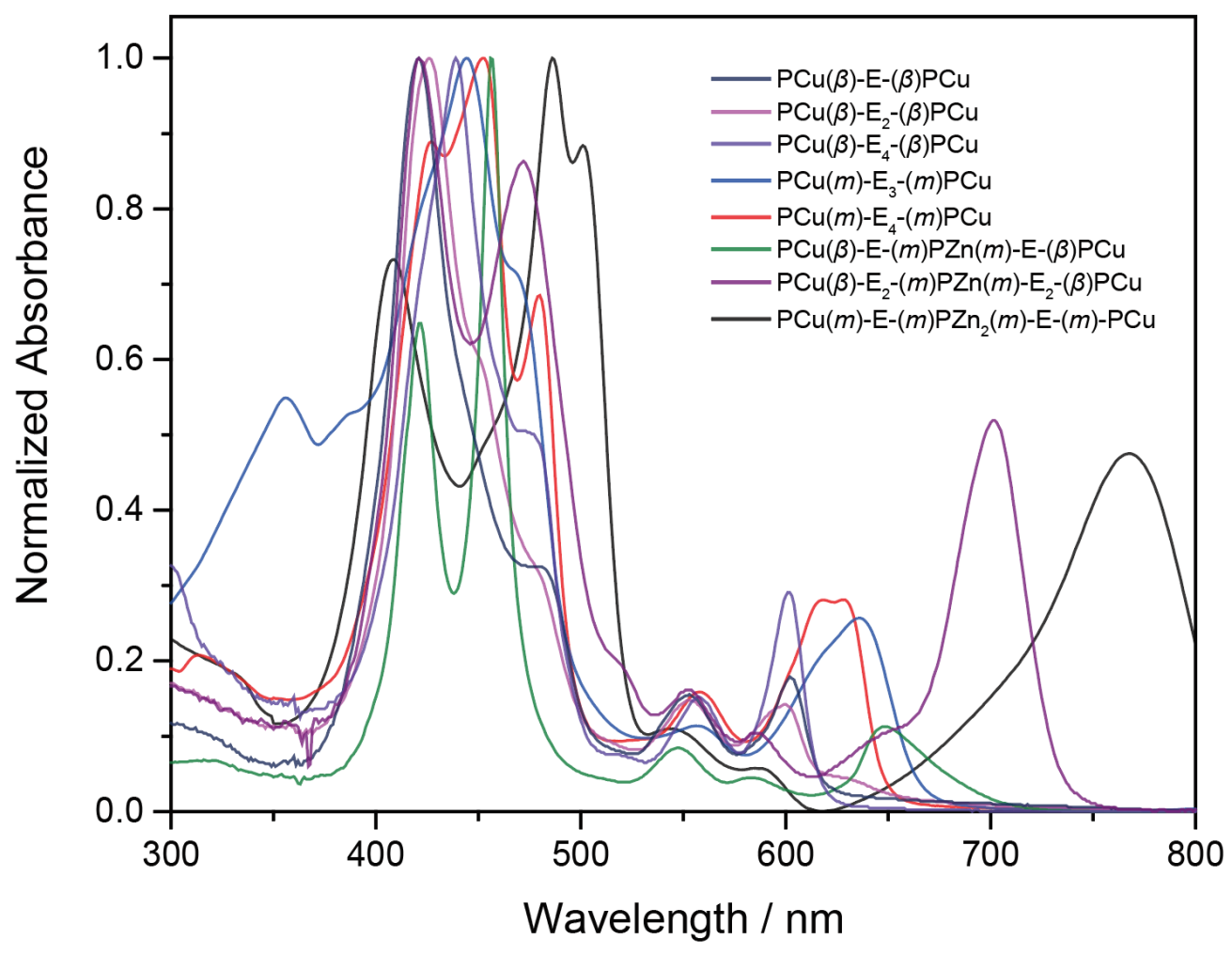

Figure S3. Normalized electronic absorption spectra of $\beta \beta-\mathrm{PCu}_{2}$ and $m m-\mathrm{PCu}_{2}$ complexes in tetrahydrofuran (THF) solvent. 
4. Additional EPR Data (Figures S4-5). The $\sigma$-type pathway of exchange coupling between unpaired spins on $\mathrm{Cu}$ ions in $\beta \beta$ - $\mathrm{PCu}_{2}$ complexes can be investigated further by temperaturedependent EPR experiments; data for $\mathrm{PCu}(\beta)-\mathrm{E}_{4}-(\beta) \mathrm{PCu}$, which highlight X-band $\mathrm{EPR}$ spectra and simulations (used to extract $J_{\text {avg }}$ ) are highlighted in Figure S5. Like $\mathrm{PCu}(m)-\mathrm{E}-(m) \mathrm{PCu},{ }^{1} \mathrm{PCu}(m)$ $\mathrm{E}_{2}-(m) \mathrm{PCu},{ }^{1} \mathrm{PCu}(\beta)-\mathrm{E}_{4}-(\beta) \mathrm{PCu}$ features a modest torsional barrier to rotation of the porphyrin rings about the bridge. The temperature-dependent EPR spectra of $\mathrm{PCu}(\beta)-\mathrm{E}_{4}-(\beta) \mathrm{PCu}$ reflects the time-averaged populations of bis $[\mathrm{PCu}]$ conformations that vary with respect to the torsional angle between the porphyrin-porphyrin least-squares planes in fluid solution. With decreasing temperature, the $J_{\text {avg }}$ value for ( $\mathrm{PCu}(m)$-E- $(m) \mathrm{PCu}$ increases over this temperature range. ${ }^{1}$ However, $J_{\text {avg }}$ for the $\mathrm{PCu}(\beta)-\mathrm{E}_{4}-(\beta) \mathrm{PCu}$ structure remains constant (Table S1), which further indicates that the electronic exchange coupling in $\mathrm{PCu}(\beta)$ - $\mathrm{E}_{4}-(\beta) \mathrm{PCu}$ is dominated by a $\sigma$-type pathway, independent of any major changes in the conformational distribution.

(a)

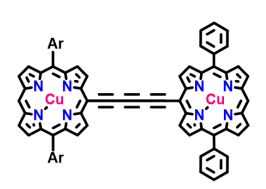

Experimental

Simulation

(b)
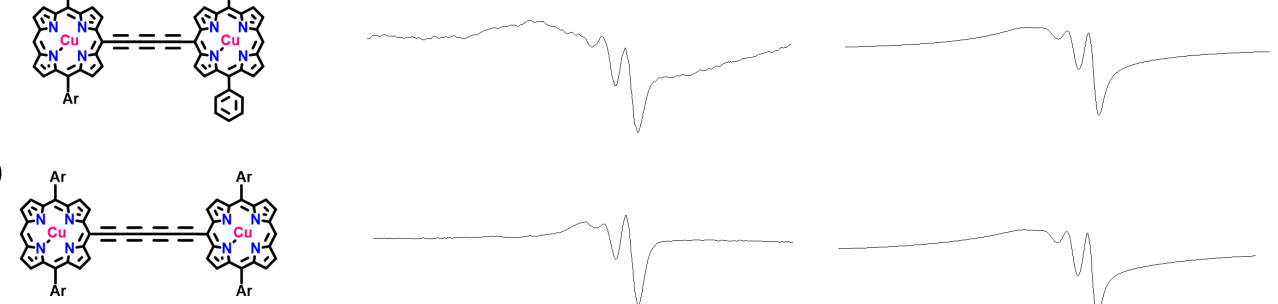

(c)
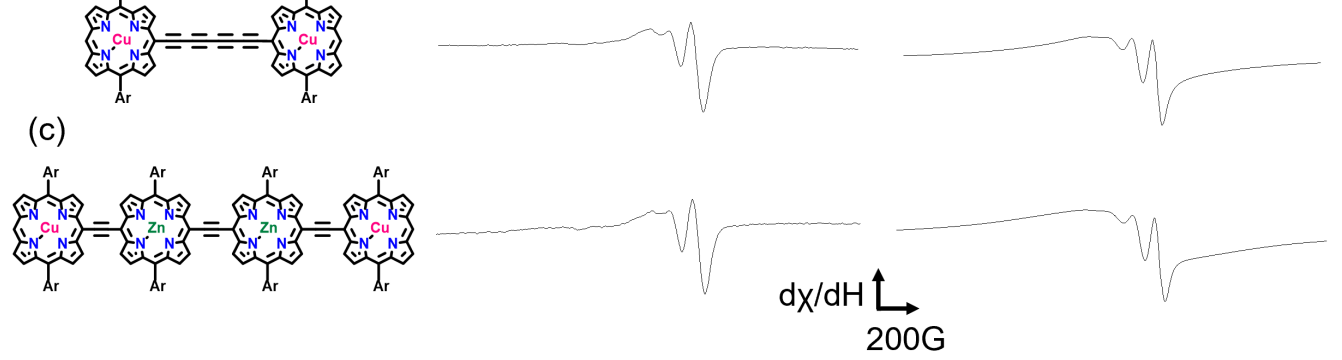

Figure S4. Steady-state X-band EPR experimental (left) and simulated (right) spectra of $\mathrm{mm}$-bridged bis[(porphinato)copper(II)] structures obtained in toluene solution at $300 \mathrm{~K}$ for: (a) $\mathrm{PCu}(m)-\mathrm{E}_{3}-(m) \mathrm{PCu}$, (b) $\mathrm{PCu}(m)-\mathrm{E}_{4}-(m) \mathrm{PCu},(\mathrm{c}) \mathrm{PCu}(m)-\mathrm{E}-(m) \mathrm{PZn}_{2}(m)-\mathrm{E}-(m) \mathrm{PCu}$. 


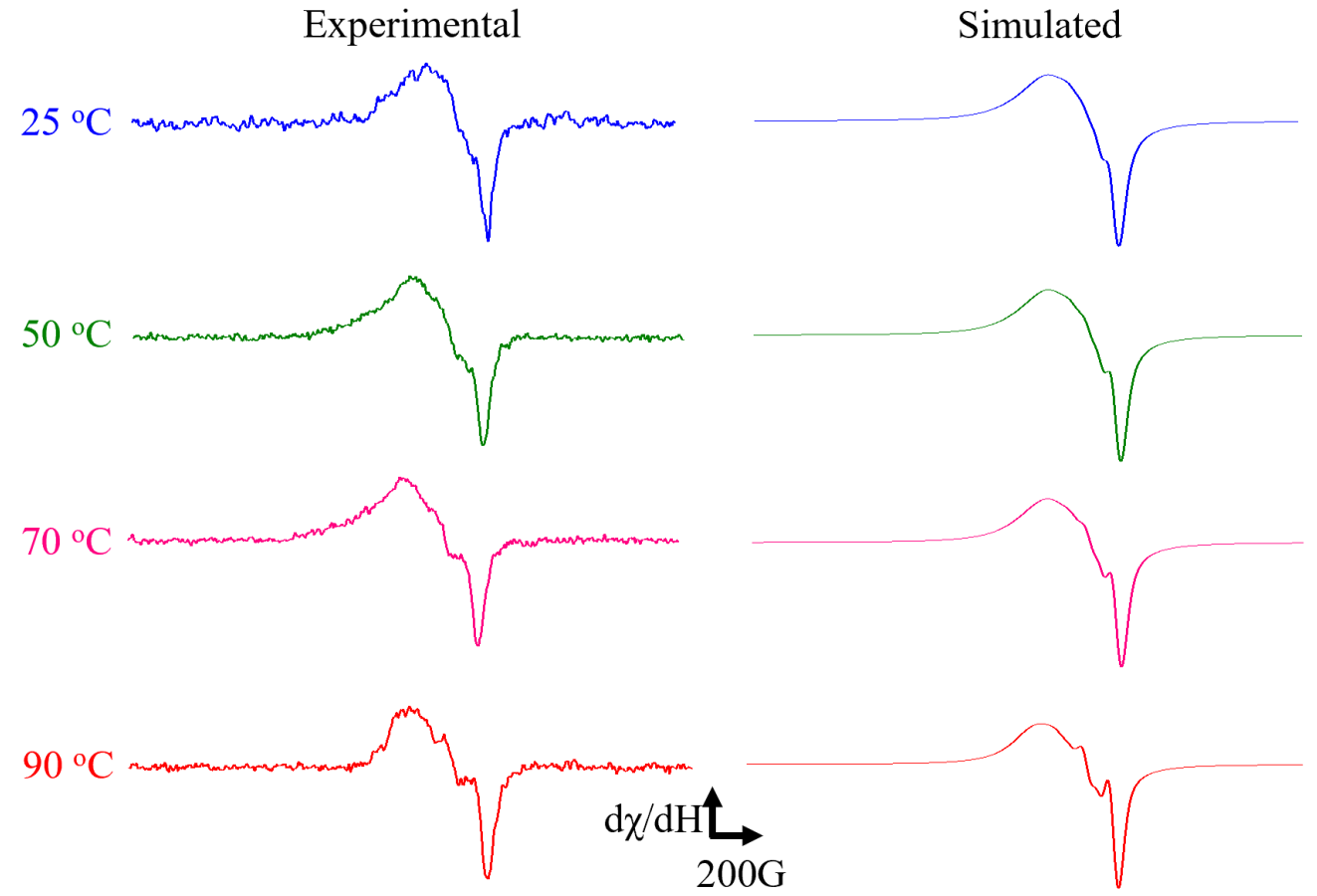

Figure S5. Temperature-dependent experimental (left) and simulated (right) EPR spectra of $\mathrm{PCu}(\beta)-\mathrm{E}_{4}-(\beta) \mathrm{PCu}$. Simulated $J_{\text {avg }}$ values are listed in Table S1. 
Table S1. Parameters used in simulations of Figure S5. The error limit of $J_{\text {avg }}$ is \pm 5 Gauss.

\begin{tabular}{|c|c|}
\hline Temp $\left({ }^{\mathbf{0}} \mathbf{C}\right)$ & $\mathbf{J}_{\text {avg }}$ (Gauss) \\
\hline 25 & 150 \\
\hline 50 & 150 \\
\hline 70 & 150 \\
\hline 90 & 150 \\
\hline
\end{tabular}

Table S2. The number of $\sigma$ bonds between the two $\mathrm{Cu}$ ions in the Chart1 bis[(porphinato)copper(II)] biradicaloid structures along with the corresponding $\mathrm{Cu}-\mathrm{Cu}$ distances. ${ }^{\text {a }}$

\begin{tabular}{|c|c|c|}
\hline Complex & $\begin{array}{c}\mathrm{Cu}-\mathbf{C u} \\
\text { Bond number }\end{array}$ & $\begin{array}{c}\mathrm{Cu}-\mathbf{C u} \\
\text { distance }(\mathbf{\AA})\end{array}$ \\
\hline $\mathrm{PCu}(\beta)-\mathrm{E}-(\beta) \mathrm{PCu}$ & 9 & 11.9 \\
\hline $\mathrm{PCu}(\beta)-\mathrm{E}_{2}-(\beta) \mathrm{PCu}$ & 11 & 14.2 \\
\hline $\mathrm{PCu}(\beta)-\mathrm{E}_{4}-(\beta) \mathrm{PCu}$ & 15 & 18.9 \\
\hline $\mathrm{PCu}(\beta)-\mathrm{E}-(m) \mathrm{PZn}(m)-\mathrm{E}-(\beta) \mathrm{PCu}$ & 18 & 21.8 \\
\hline $\mathrm{PCu}(\beta)-\mathrm{E}_{2}-(m) \mathrm{PZn}(m)-\mathrm{E}_{2}-(\beta) \mathrm{PCu}$ & 22 & 26.8 \\
\hline $\mathrm{PCu}(m)-\mathrm{E}-(m) \mathrm{PCu}$ & 9 & 10.4 \\
\hline $\mathrm{PCu}(m)-\mathrm{E}_{2}-(m) \mathrm{PCu}$ & 11 & 12.7 \\
\hline $\mathrm{PCu}(m)-\mathrm{E}_{3}-(m) \mathrm{PCu}$ & 13 & 15.2 \\
\hline $\mathrm{PCu}(m)-\mathrm{E}_{4}-(m) \mathrm{PCu}$ & 15 & 17.6 \\
\hline $\mathrm{PCu}(m)-\mathrm{E}-(m) \mathrm{PZn}_{2}(m)-\mathrm{E}-(m) \mathrm{PCu}$ & 18 & 20.7 \\
\hline $\mathrm{PCu}(m)-\mathrm{E}-(m) \mathrm{PZn}_{2}(m)-\mathrm{E}-(m) \mathrm{PCu}$ & 27 & 40.0 \\
\hline
\end{tabular}

${ }^{a}$ The $\mathrm{Cu}-\mathrm{Cu}$ bond number corresponds to the shortest through $\sigma$ bond coupling pathway, while the $\mathrm{Cu}-\mathrm{Cu}$ distance corresponds to the through-space distance, that separates the two $\mathrm{Cu}$ centers. 


\section{References}

(1) Avdievich, N. I.; Dukes, K. E.; Forbes, M. D. E.; DeSimone, J. M., Time-Resolved EPR Study of a 1.9-flexible Biradical Dissolved in Liquid Carbon Dioxide. Observation of a New Spinrelaxation Phenomenon: Alternating Intensities in Spin-correlated Radical Pair Spectra. J. Phys. Chem. A 1997, 101, 617-621.

(2) Wang, R.; Brugh, A. M.; Rawson, J.; Therien, M. J.; Forbes, M. D. E., Alkyne-Bridged Multi[Copper(II) Porphyrin] Structures: Nuances of Orbital Symmetry in Long-Range, ThroughBond Mediated, Isotropic Spin Exchange Interactions. J. Am. Chem. Soc. 2017, 139, 9759-9762.

(3) Lin, V. S.-Y.; DiMagno, S. G.; Therien, M. J., Highly Conjugated, Acetylenyl Bridged Porphyrins: New Models for Light-harvesting Antenna Systems. Science 1994, 264, 1105-1111.

(4) Susumu, K.; Therien, M. J., Decoupling Optical and Potentiometric Band Gaps in $\pi$ Conjugated Materials. J. Am. Chem. Soc. 2002, 124, 8550-8552.

(5) Bai, Y.; Olivier, J.-H.; Yoo, H.; Polizzi, N. F.; Park, J.; Rawson, J.; Therien, M. J., Molecular Road Map to Tuning Ground State Absorption and Excited State Dynamics of Long-Wavelength Absorbers. J. Am. Chem. Soc. 2017, 139, 16946-16958.

(6) Lin, V. S.-Y.; Therien, M. J., The Role of Porphyrin-to-Porphyrin Linkage Topology in the Extensive Modulation of the Absorptive and Emissive Properties of a Series of Ethynyl- and Butadiynyl-Bridged Bis- and Tris(porphinato)zinc Chromophores. Chem. -Eur. J. 1995, 1, 645651. 